\title{
Counteracting Radicalism with Cultural Communication in Religious Practices
}

\author{
Rachmat Kriyantono \\ School of Communication. \\ Brawijaya University, Malang, Indonesia
}

\begin{abstract}
This study aims to analyze the relationship between religious habits and radical behavior (terrorism). It is assumed that individuals who adopt cultural values in practicing religious worship will not carry out terrorist activities. Religion is not only a relationship with God but also a relationship with society. This research uses content analysis method on terrorism news in online media. This research found that most terrorists are people who do not have good quality social relations with the community, tend to be closed and aloof from social relations. Terrorists also do not engage in religious activities together, including not making culture a religious instrument. This research contributes to developing the study of terrorism communication in the Indonesian context.
\end{abstract}

\section{INTRODUCTION}

Cultural studies is very important in communication science, as reflected in the opinion of Dissayanake (2003) who mentions culture without communication cannot breathe, and Fiske (2002) who states that communication is the core of developing culture, without communication, culture will die. All types of communication processes occur in cultural contexts (Ayish, 2003; Carey, 2009; Fiske, 2002; Kriyantono, 2017a). Communication reflects the culture of a society, as Carey (2009) said that communication as a culture and Edward T. Hall said that communication is culture, culture is communication (Gudykunst \& Lee, 2002).

Culture is "a way of life that develops, and is shared by a group of people, and is passed down from generation to generation" (Gudykunst \& Lee, 2002), which is manifested in the form of artifacts, behavior patterns, thought systems, and ideologies (Kriyantono, 2019). If the culture has the ability to face the influence of foreign culture when the two cultures are related, then it is called local wisdom (local genius/wisdom) (Rosidi, 2011). This cultural ability, referring to Radmila (2011), is possible because the local community has local wisdom in the form of local (local) ideas or ideas that contain values of wisdom and goodness, which are hereditary (inherited). Internalization, that has become a tradition, occurs because this local wisdom is both a message and a strategy for delivering messages (Kriyantono, 2019). Local wisdom contains messages of information sharing, socialization, dissemination of cultural values, education, and social control delivered through various communication media, such as fairy tales, gethok tular (word of mouth), cangkrukan (chatting to each other casually in groups), arts (ludruk \& ketoprak/traditional drama, puppets), tembang (traditional songs), proverb, and sinoman (traditional society in Java). For example, "values of respecting others are conveyed using Javanese ngoko (everyday language) or kromo (language of respect for parents or respected people)." (Kriyantono, 2017a, p. 346).

Culture, embodied in this local wisdom, together with this personal backgrounds and sociodemographic characters, refers to Wood (2009), which makes communication systemic. "To interpret communication, we have to consider the system in which it takes place." (Wood, 
2009, p. 4). In other words, communication can be effective if individuals know their audience (communicant/public), that is, individuals or groups of individuals who possess various characteristics, including cultural characteristics (Kriyantono, 2017). Understanding this communicant is trying to create a common background between the communicator and the communicant, called homophile. Similarities will occur if both the terms of reference and the field of experience between communicator and audience are overlap, called the focus of interest, which makes communication work in the same sense.

The description above is in line with the word of God that humans were created in different nationalities, tribes, ethnics, therefore, they must know each other. A person's devotion is not seen from personal labels, such as national pride, ethnicity, or other socio-demographic factors, but, based on devotion to God (Moslem calls Allah). This Word is the first Multiculturalism theory offered by Islam before the multiculturalism theories that developed in the United States. The latest only emerged after World War II when the US was at war with slavery. This theory of Islamic Multiculturalism not only commands worship to Allah but also worship in humanity. Culture eventually becomes an instrument to explore this humanist aspect of humanity. Culture makes humans more humane, including more humanistic in carrying out religious worship. Being humanist in religion is very important because religion teaches an individual to become humane, that is to love, respect, and love other human beings in all their deeds.

Humans are social creatures that have just developed their humanity through social interaction because humans are always communicating and communicating is a marker of interaction. O'Hair \& Eadie (2010, p. 3) calls communication a "ubiquitous phenomenon" (always present and unavoidable). Lucien Sfes also called "homo communicans" (Simonson, et al, 2013, p. 7), that is, humans are creatures that always communicate. Palo Alto's scientist, Janet Bavelas (1990), said "All behaviour is not communication", but "One probably cannot avoid communicating in a social setting" (Rogers, 1997). It means that there can be actions that are considered not communication, such as sleep, but, when sleep causes meaning for others, then sleep can be called communication (Kriyantono, 2019). All production and reproduction in social life that is so complex and detailed occurs through communication, namely the relationship between social symbols and structures and these relationships that create, maintain, and transform society (Carey, 2009).

If it is associated with the above definition of culture, social interaction produces culture and culture will affect interaction. Social interaction occurs in all human life, politics, economics, including in religious practice. This is reinforced by the words of the Prophet Muhammad that religion is interaction (Shihab, 2013).

It can be concluded from the description above that religion is humanistic. Religion teaches humans to be humane, that is, to establish a relationship with God and a relationship with fellow human beings. A human can be called a whole person if it does not lose its humanistic nature. This humanistic nature can be honed through social interactions that produce culture so that culture is an instrument for the creation of human human nature.

On the other hand, there is a phenomenon of violence that uses religion as an instrument and this phenomenon is popular with the concept of radicalism (Widyaningrum \& Dugis, 2018). This phenomenon is recognized by Armstrong (2006) to occur in all religions in the world. "Radicalism is often associated with the concept of religion which is then often called religious radicalism so that it becomes a problem related to core experience, collective memory and interpretation of religion (Zuhdi, 2017, p. 199). Religion is often used to stimulate violence, 
according to Haryatmoko (2014), because of the way to teach religion that is not in accordance with the correct guidance. Many stories about religious lessons have been used as brainwashing tools since childhood by religious teachers, religious leaders or preachers circulating in the community "(Haryatmoko, 2014, p. 114).

Radicalism continues to turn into acts of terrorism. In a critical perspective, every movement based on radicalism must be shrouded in a certain political agenda of power which is used by certain parties to make the radicalism movement as an act of terrorism. This radical movement is frequently used as a cover for resistance to the government system or just to spread terror in the community (Widyaningrum \& Dugis, 2018).

The debate about the perpetrators and motives of terrorism often leads to the identification of ideology or religion of the terrorist, because ideology or religion is a source of legitimacy from the action. The state gets the legitimacy of violence or terror because of its sovereignty or constitutional authority, while community groups usually get legitimacy from ideology or religion (Khairil, 2012). People who are said to be radical are those who want a change in the existing situation by breaking into its roots, liking rapid and fundamental changes in government laws and methods (Kusuma \& Azizah, 2018).

Based on the relationship of interaction, culture, and religion described above, the researcher believes that the nature of humanism in religion that can be a deterrent to violence or radicalism in the name of religion. People who are accustomed to waking up their humanist aspects of worship will awaken a sense of love for their fellow humans despite differences between people.

From preliminary observations at An-Namiroh Mosque, Tegalgondo Village, Malang Regency, East Java, researchers found a ritual shaking hands with worshipers who sat on the right and left after saying salam (greetings) in prayer. The worshipers (jama'ah) also performed shaking hands with all the worshipers after the imam (Leader of sholat/prayer) read the prayer, standing in line while reading the sholawat (Prophet's prayer), before separating from the mosque. This is a ritual communication for generations. Indeed, not all worshipers do it, depending on their interpretation of religious teachings.

This handshake ritual communication has relevance to the local wisdom of our nation, that is, a nation that likes to bring harmony, that individuals as jagad cilik (small-universe) entities cannot be separated from the jagad-gedhe (wider-universe: the wider social system, including neighbors), guyub rukun (get along well), mangan gak mangan sing penting ngumpul (eat not eat important to gather), and live in harmony. Indeed, this ritual is not a compulsory pillar of prayer, but, this ritual is an attempt to represent the teachings of the Prophet Muhammad about ukhuwah (unity of the people), silaturahim (friendship in the midst of differences), and respect for the Messenger of Allah with compassion. This ritual communication, provides the opportunity for the worshipers to feel the beauty of the difference because there are worshipers who perform rituals and some do not. Friendship are maintained. This cultural communication also implements another teaching from Prophet Muhammad, which is to forgive one another (a handshake can be interpreted as a symbol of forgiveness and brotherhood) as an anticipation of mistakes, whether intentionally or not, during the interaction of performing the prayer (sholat). The beauty of this culture should be preserved as Indonesian character and personality in carrying out worship to God.

There are many more examples of religious activities using local cultural traditions. The activities of using Indonesian local cultural tradition in Islamic worships can be called Islam 
Nusantara (Nusantara is another name of Indonesia). In addition to the tradition of shaking hands, the community performed tahlilan (pray with neighbours for parent who have died), mudik (homecoming culture), halal bi halal (gathering to ask forgiveness), and Maulid Nabi (commemoration of the Birthday of the Prophet Muhammad). All of that departs from the character of our nation that promotes togetherness and harmony. The culture of our society in worship is the result of the mind that wants to express its human aspects so that culture is able to maintain the humanistic nature of our society. Wali Songo (Nine Moslem teachers who spread Islam in Indonesia) and other kyai (propagators of Islam) in Indonesia use culture so that Islamic teachings were more easily accepted, understood, and implemented. Wali Songo and other scholars were people who were pious and had a high understanding of religious knowledge so that the culture they taught in spreading Islam did not conflict with the teachings of Islam itself. The culture was packaged based on the arguments of the Qur'an (the Holy Book of Islam) and the Hadith (collection of words and deeds of the Prophet Muhammad). All of these teachings have been inherited by Moslems until now.

In Indonesia as an agrarian country, a culture of togetherness is very pronounced in people who are accustomed to living managing nature together. The culture of an agrarian society is strongly influenced by Islam (Hasbiyallah, 2006, Kriyantono, 2017a). Islam is the majority religion adopted by the people of Indonesia (Federspiel, 1998; Rachman, 2010). The number of Muslims in Indonesia contributes to $12.9 \%$ of the world's Muslim population (Pew Research Center, 2009).

Regarding culture, Islamic values have undergone a process of acculturation and assimilation of the culture of Indonesian people (Kriyantono, 2014a; Ramayulis, 2010). Arifin said that "... Islamic values are infused with peace without eliminating local customary values which are in accordance with or not in conflict with Islamic values and Islamic law" (1996, p. 34). It can be understood that Islamic values do not eliminate the customs of Indonesian society that existed before Islam came, but, interact with each other until there is an adjustment between the two.

The process can be proven by the proverb that comes from the culture of Madurese people (one of the ethnics), namely "abantal syahadat asapo iman" which means having a creed, covered in faith (Amirullah, 2015; Kriyantono, 2017). This proverb becomes a guideline for the Madurese community that the balance of life is the maintained relationship to God and with others and the balance between worldly interests and the hereafter (Amirullah, 2015).

Furthermore, the Javanese communities have also the proverb "agama ageming aji" which means religion is a valuable dress (Kriyantono, 2017a). In Javanese society, Islam is a guideline for the people to achieve harmony, safety, and welfare of life which is realized by making religion a bastion of courtesy, upholding humanity, justice, and truth (Anshoriy, 2010). While the Minangkabau people has the proverb "adat basandi syarak, syariah basandi kitabullah" which means the customs are based on sharia (sharia means Islamic teaching), sharia based on the Holy Qur'an (Kriyantono, 2019). Ramayusli explained that the Minang community would not call it a Minang custom if the custom contradicted Islamic values (2010). From this proverb it can be seen that Islam has become a role model that is entrenched in the societies and shows its observance as a Moslem.

The influence of Islam on the culture of Indonesian society can also be explained theoretically because according to Koenjtaraningrat (2011) religion is one element in the formation of a culture is religion. Jensen also stated that (2013) religion is the main element of culture that functions to shape one's cognition both individually and collectively. If so, then it can be 
concluded that religion has an important role in the formation of a culture in certain community groups.

Research that shows the influence of religion on the culture of its people was also successfully advanced by Ayish (2003). According to Ayish (2003) based on the Arab-Islamic perspective, there are four characteristics of communication that are applied by Arab society, including, namely, individualism-conformity, transcendentalism-exixtentialism, intuitive-rational processes, and egalitarianism-hierarchy. The four ideas are a combination of two components, namely the secular component derived from Arabic culture and the Islamic component derived from Islamic values such as monotheism (no god but Allah), faith (trust), ummah (community), worship, and science (ilm) (Ayish, 2003). From these explanations, it can be concluded that the majority religion in a particular region will very likely have a major influence on the culture of its people, as happened in the culture of Indonesian people (Amirullah, 2015; Kriyantono, 2014a). Therefore, it can be said that the local culture of Indonesian people has conformity with the values of Islamic teachings.

The researcher believes that the practice of religious worship that adopts local culture, namely the culture of togetherness, such as shaking hands and pray together, is able to train the nature of togetherness with fellow believers. In the end, it raises a sense of compassion and a sense of heart that cannot kill other humans through acts of terror. The importance of local culture to counter radicalism is also reinforced by the fact that radicalism is a global action due to globalization. Globalization has driven an increase in terrorist activities. On the other hand, terrorists use globalization instruments like the internet to spread the threat of widespread fear (Ghifari, 2017).

In this study, the researcher wants to confirm the research assumption that radical actors are individuals who do not adopt the cultural values of togetherness in religious practice. To prove this, researchers conducted a qualitative content analysis of news in the media about the religious practices of the perpetrators of radicalism who carry out acts of terrors in the community. This current research contributes to develop communication studies in the context of the relationship between radicalism, culture, and religion. It is hoped to open awareness to maintain local culture which is proven to be an instrument of building togetherness.

\section{RESEARCH METHOD}

This study uses a qualitative content analysis method. Qualitative content analysis, according to Bibber \& Leavy (2005, p. 1278) is "a research method for subjective interpretation of text data content through a process of classification and identification of themes or patterns systematically." This qualitative content analysis is systematic, analytical but not as rigid as in quantitative content analysis. Categorization is used only as a guide, allowing other concepts or categories to emerge during the research process.

In this study, the unit of analysis is a reference, a series of words or sentences that indicate something that has meaning according to the category of religious habits. The Researcher collected terrorism news and analysed the religious habits of the terrorists depicted in the news. Content analysis is carried out on 25 online news that examines the behaviour of terrorists in everyday life.

\section{RESULTS AND DISCUSSION}

In this section, researchers present the results of news content analysis based on the categorization based on the tendency of news content. Researchers found categories of 
terrorist religious habits include: The use of symbols, such as how to use the religious symbols; religious habits; and social interaction habits.

\section{THE USE OF RELIGIOUS SYMBOLS}

It appears that terrorists use religious symbols that are different from the surrounding community. From a number of terrorism cases, it was reported that terrorists changed their way of dress and physical appearance when they decided to act terror. The characteristics of how to dress are often wearing gamis (called jubbah/robes), which is the traditional clothing of the Arabs. A robe or a cloak is a kind of clothes that are dominantly used in the Middle East and Islamic countries. This shirt in Arabic is called Tsaub, disydasya, kandurah, also khomis (in Somali language). The term gamis is derived from the word Khomis. In addition, if they wear pants, these terrorists prefer to wear celana cingkrang (short pants, above the ankles). Like the following news:

Rofik, a brother-in-law of the suspect BW, tells about BW's habits: "He became a religious about seven years ago. Once the person stubborn, in the sense of like to gamble. Do not want to pray, and his brother often advised him so that BW would pray. According to him after getting continuous advice, finally BW totally changed. The change was even more apparent, he explained, when BW migrated to Jakarta. After leaving Jakarta, he suddenly diligently worshiped. The way to dress changes, like to wear a pair of trousers. But if the socialization is still like before. That means there is no change." (Pos Belitung, June 2, 2018).

The Head of RT (Neighborhood Association), RW (Citizens Association) II, Sidosermo Village, Wonocolo District, Surabaya, told the story of a terrorist named IM: "Changes in the way of dress and activities are striking in Aiunun's eyes because IM and his wife look more religious. In addition to veiling, the wife last year also appeared to wear a veil when leaving the house. "Previously, FT did not wear hijab or veil. In addition to FT, IM as the head of the family also began to change since the FT change during this year. It's just that IM itself is more likely to change in the way clothes are about to pray five times a day. IM also changes from clothes when they want to pray. Previously he was not very active in his prayers and his clothes did not look bloated (Beritajatim.com, 17 August 2019).

Clothing material used is not from fabric in general, but, fabric cloth "ngatung" or like "burlap" fabric. For physical appearance, the terrorists have the character of having beards on their faces. As the following news: "In addition, since five years ago IM has never maintained his beard and since a few months IM extended it" (Beritajatim, 17 August 2019).

It is important to note that gamis robe is not original clothes from Indonesia. The gamis robe or traditionally called abaya is a plain black robe worn by Moslem to cover their ordinary clothes. It can be described as a long-sleeved robe-like dress and it is the traditional form of clothing for many countries on the Arabian Peninsula including Saudi Arabia and United Arab Emirates. In Iran this abaya is called a chador and in South Asia the burqa. For women, the robes cover the entire body except the face, legs and hands. This can be worn with niqab, a face veils covering all but the eyes. The origin of the robe is not clear. Some people argue that it existed for 4000 years ago in the ancient civilization of Mesopotamia and when Islam emerged in the seventh century, religion absorbed the practice of local headscarves into culture, perhaps because of the tradition of dressing the Arab female in the era of Jahiliyah (before Islamic era). Some people argue that the idea of 'body cover' is more about class levels than about religion. In pre-Islamic, a hijab in the Arabian Peninsula was seen as a sign of privilege and luxury given to women who do not have to work. They are distinguished from slave girls and prostitutes, who are not permitted to cover the body, and nomadic and rural women who are too busy 
working so that they need practical clothes to cover their faces and an extra layer of clothing that does not interfere with their activities.

\section{RELIGIOUS HABITS}

From media reports, data are obtained that terrorists are considered to be very diligent in worshiping, namely worshiping in relation to God, namely prayer. They diligently pray at the mosque even though the mosque is in a location far from his home. They are very punctual in prayer. As the following news:

Changes in dress and activities are striking in Ainun's eyes because IM and his wife are more religious. A striking change was also seen in IM who used to worship in a musala near home. But the past year has always been worshiping at a mosque that is almost one kilometer away from his boarding house (Beritajatim, August 17, 2019).

The news about the terrorist behavior named Hadi, also explained:

Hamidin explained that the first son of three siblings was indeed known to be a quiet person and never did mischief like other young people. He is very diligent in worship. Almost every night Hadi said that Hamidi routinely attended the Koran recitation activities in the mosque so he assumed his child was a good child and could not possibly be involved in criminal or terrorist activities. What's wrong with her diligent Koran? As far as I know there is nothing wrong so far in the way he believes in his religion (Islam). He is an obedient child. Indeed, Hadi said that Hamidi was rather prominent in exploring and practicing his religious teachings, but as a parent Hamidi was even grateful that his son was a devout worship and worship. He always brings the Koran and religious books when he goes out, but that is a natural thing as a Muslim (jpnn, August 16, 2016).

Another example is the story of a terrorist named Yusuf. Yusuf's mother, Zahriana, said that her third child had only taken the last 15 days to attend one of the Koran studies, which she did not know where she was. After the recitation I saw him still praying, doing God's commands well. But every time he prayed he always said, "Mother pray, later if you do not pray large sins. Abandon his great sin obligation "(motorplus-online.com, May 17, 2018).

On the other hand, the terrorists are depicted not doing worship related to human relations as is the custom of the people around them. It is described in the following news:

According to the neighbour, Ivan's participation in terrorist activities was very unexpected, with his character in the community and perseverance in worship. But his family and community are suspicious of Ivan because his spiritual activities provoke controversy. He often repeated his prayers even though he had previously prayed in congregation (www.viva.co.id).

Neighbors of the terrorists who bombed several churches in Surabaya (May 2018) told that the terrorist family never carried out cultural rituals in prayer. They always come late (when the prayer starts) and immediately go home after saying the closing prayer. They never shake hands, dhikr and pray together. That is, the nature of togetherness with fellow people has not been trained. A terrorist secured by Detachment 88, SA, residents of Candirejo Village, Magetan Regency, East Java, are known as people who can get along with the community. Head of RT 01 RW 01 Candirejo Village Hariyanto said, SA used to take part in social activities such as community service activities held in the environment. "It is good for people who are social in the environment, only salvation with RT social gathering, he does not participate. Maybe it's related to his belief, "he said Thursday (07/04/2019). Hariyanto explained, related to the habits of the SA who had never participated in the activities of the rescuers and the social 
gathering of the residents, they considered it normal. In daily life, the SA family is no different from other people in terms of clothing. "It's normal to dress, if there are activities such as social gathering in their groups, it's not necessarily once a month," he said (Kompas.com).

\section{SOCIAL INTERACTION HABITS}

The data findings also show that there are two types of ways in which social interaction is carried out by terrorists. First, terrorists who tend to have the habit of interacting with neighbors just like other citizens in general. Indeed there is a change in behavior, i.e., studying Islam more and more diligent in worship. This habit of interacting is no different from other residents often making many neighbors who do not believe when the terrorists are arrested by the police. This is seen in the following news excerpt:

The suspected terrorist Ivan Rahmat Syarif who is domiciled in Tani Mulya Village, Ngamprah District, West Bandung Regency, West Java, was a seller of marrow porridge before participating in radical ideology and was arrested ambushed in Purwakarta. Ivan's relative, Ombi Sutisna, explained that he was pursuing his marrow porridge business by going around. In everyday life, Ivan is known as a figure who diligently praying in congregation in the mosque near his home. In terms of clothing, Ombi continued, he always wore simple clothes. Not flashy either during community events or when praying in congregation in the mosque. "Around, sometimes like in one place. Previously often together, the same brother. His appearance was normal," Ombi told reporters on Monday, December 26, 2016. According to him, Ivan's participation in terrorist activities was very unexpected. Because the word Ombi, with its character in the community and perseverance in worship (www.viva.co.id).

Second, terrorists who tend to be closed and are not used to interact with the surrounding community. As an example of the following news:

Abdul admitted that he really did not think that his number nine child was involved in a terrorism case. The father of eleven children said, MA is a figure of a quiet child, not adventurous, acting like a child in general. "Indeed he (MA) rarely gets along, rather quietly than the other siblings," Abdul said. The most prominent habit, according to his father, is quiet, if he wants to do it, he doesn't say anything, he doesn't demand anything. Abdul also did not think that his son kept explosives in the house he shared with his son-in-law and his grandchildren (www. Alinea.id).

Abdul Ghani, 69, said his son, who is now suspected of being a suspected terrorist, is Muhammad Arshad (21) often staying at home when not working. Arshad, who works as a factory worker, is said to rarely get along. "In this neighborhood, he never hangs out," Abdul Ghani said at his home, Belibis V street, Semper Barat, Cilincing, North Jakarta, Monday, 23 September 2019. Arshad was also shown his quiet attitude to his parents. According to Abdul, his ninth child was indeed closed. "When asked where are you going? Just keep quiet, just wander off, don't answer," (Tempo.co.id).

Often the public does not know for certain the background of these terrorists, especially terrorists who are migrants. These terrorists usually rent a house of one of the residents. Here are examples of news related to this terrorist habit:

Little is known by residents of the daily activities of five suspected terrorists who contracted in Bambang's home in Rawadas Village RT 01/02, Pondok Kopi, East Jakarta. To the knowledge of the residents, the five terrorist suspects with the initials $A, D, M, R$ and $A$ seem like other ordinary citizens even though they rarely associate with the surrounding environment. Nothing is odd. However, one of the M book bomb terror suspects who used to peddle children's toys has another habit than most toy 
traders. "Heard from other merchants, he (M) if again quiet often read books," said a neighbor who did not want to be named to Legal on Saturday (4/23/2011). The owner of this small shop also had a suspicion of an unfriendly M like ordinary toy hawkers behave. Even though in his neighbourhood there were many children who gathered around to play, M only passed, he chose to stay at Elementary School (SD) Nurul Islam and SD 03 Malaka, Pondok Kopi. "My son at that time cried asking for a toy, but I called him (M) not to answer and went straight back to his contract," the story of this mother.

Based on data obtained from various news, it can be said that religious behaviour that emphasizes the aspect of togetherness is very important to prevent radical behaviour. Indonesia is a country that still relies on social interaction as a culture that cannot be replaced just like that. The Idul Fitri (the Holy Day of Islam) celebrations that occur every year are a phenomenon that shows these values. The family in Javanese culture (the majority tribe in Indonesia) is considered very important. The principle of mangan ora mangan sing penting ngumpul is an expression that how important family values are held above biological interests, namely eating. This high kinship relationship is actualized in communicating with questions that are considered by Western society as very personal questions, namely regarding marital status, age, domicile, occupation, educational history, and other personal issues. For the people of Indonesia in general and Java in particular, asking these things in a phatic communication (for example, when the initial conversation meets) is fairness as a social radar to establish intimacy.

The kinship above is also represented in the concept of 'shared property', which is a concept that refers to a sense of community in the property. For example, the Javanese community has a mosque, village grave, and a sinoman system. The Javanese people assume there is a shared responsibility to protect the property, even though the property is privately owned. If one resident builds a house, neighbours and close relatives help as a volunteer. If there are residents who have a desire or distress due to death, the neighbors come to provide assistance. The mothers brought rice, sugar or dried noodles, the fathers assisted in physical work, such as setting up tents, chairs and carriages/cangkruk. This is referred to as "mutual cooperation". The food that the neighbours bring can help the family of the deceased party to hold a prayer together (tahlilan).

The concept of mutual cooperation is still apparent in rural areas when residents build public facilities and because they feel like a family, they tend to be non-profit oriented. According to J. Sullivan (1991, p.1), "mutual cooperation is an ideology that something is essential to all societies which helps reproduce social orders." Because they occupy the village area from birth, they know each other and have a sense of togetherness. Land and houses not only have economic significance but also cultural value. Houses and land are proofs of the existence of ancestors and is an honor to preserve and preserve ancestral heritage.

\section{CONCLUSION}

This research proves that there is a relationship between religious habits and the tendency to become terrorists. The terrorists have different religious habits from other members of the community. In general, these terrorists tend to be closed and do not participate in religious activities that contain social values together. These terrorists are indeed more focused on worship, in a sense, building relationships with God, but, they are not focused on activities to build social relations with the community. 
This research has limitations because it only analyzes based on news excerpts about the daily activities of the terrorists. It is necessary to examine the motives and daily habits of terrorists through direct interviews with them so that in-depth and natural data are obtained. Therefore, for future research in the future, researchers recommend ethnography and in-depth interviews. It is hoped that this research can enrich scientific studies related to relations of communication and terrorism.

\section{References}

Amirullah. (2015). Islam di Madura. Islamuna, 2, 56-69.

Ayish, M.I. (2003). Beyond western-oriented communication theories a normative Arab Islamic perspective, Journal of the European Institute for Communication and Culture, 10(2), 79-92.

Hsee-Bibber, S.N., \& Leavy, P. The Practice of Qualitative Research. California: Sage. 2006.

Carey, J.W. (2009). Communication as culture: Essay on media and society. Revised edtion. New York: Routledge.

Dissanayake, W. (1988). The need for Asian approaches to communication. In Communication theory: The Asian perspective. Singapura: AMIC.

Fiske, J. (2002). Introduction to communication studies. New York: Routledge-Taylor \& Francis e-Library.

Ghifari, I. E. (2017). Radikalisme di internet. Religious: Jurnal Agama dan Lintas Budaya 1, 2 (Maret 2017): 123134.

Gudykunst, W.B., \& Mody, B.B. (2002). Introduction of intercultural communication. Di Handbook of international \& intercultural communication. Gudykunst, W.B., \& Mody, B.B. (Ed.). California: Sage Publications.

Kriyantono, R. (2019). Pengantar lengkap ilmu komunikasi: Filsafat dan etika ilmunya serta perspektif Islam. Jakarta: Prenada.

Kriyantono, R. (2017a). Teori public relations perspektif barat \& lokal: Aplikasinya dalam penelitian dan praktik. Jakarta: Prenada.

Michigan State University. Northeast African Studies Committee, Northeast African Studies, Volume 8, (African Studies Center, Michigan State University: 2001), p.66.

O'Hair, H. D., \& Eadie, W. F. (2010). Communication as an idea and as an ideal. In Eadie W. F. (Ed.). 21 ${ }^{\text {st }}$ century of communication: A refereed handbook. California: Sage Publications.

Radmilla, S. (2011). Kearifan lokal: Benteng kerukunan. Jakarta: Gading Inti Prima.

Rogers, E.M. (1997). A history of communication study: A biographical approach. New York: The Free Press.

Rosidi, A. (2011). Kearifan lokal dalam perspektif budaya Sunda. Bandung: Kiblat.

Simonson, P., Peck, J., Craig. R.T., Jackson Jr., P.J. (2013). The history of communication history. Dalam Simonson P., Peck, J., Craig, R.T., Jackson Jr. (Eds.). The handbook of communication history. New York: Routledge.

Sullivan, J. (1991). Inventing and imagining community: Two modern indonesia ideologies. The Centre of Southeast Asian Studies Monash University, 69.

Widyaningrum, A. Y., \& Dugis, N. S. (2018). Terorisme, radikalisme, dan identitas ke-Indonesiaan. Jurnal Studi Komunikasi, 2(1), 32-67.

Wood, J. T. (2011). Communication mosaics: An introduction to the field of communication. Boston: Wadsworth https://www.viva.co.id/berita/nasional/863604-terduga-teroris-purwakarta-pedagang-bubur-sumsum https://regional.kompas.com/read/2019/07/04/10502851/terduga-teroris-di-magetan-tak-pernah-mau-ikutselamatan-dan-arisan.

https://www.alinea.id/nasional/terduga-teroris-cilincing-tukang-service-hp-b1XmK9n5j

https://metro.tempo.co/read/1251341/terduga-teroris-cilincing-jarang-bergaul-tapi-rajin-ke-bekasi 